\title{
Giant Parotid Pleomorphic Adenoma Involving Parapharyngeal Space
}

\author{
Sukri Rahman, Bestari J Budiman, Yurni
}

\begin{abstract}
Abstrak
Latar belakang: Pleomorfik adenoma parotis merupakan tumor jinak kelenjar liur yang paling sering ditemukan, namun pleomorfik adenoma parotis yang sangat besar sehingga melibatkan ruang parafaring (RPF) sangat jarang. Diagnosis ini sulit ditegakkan karena gejala klinisnya tidak khas. Penatalaksanaanya harus hati-hati mengingat banyak struktur vital yang beresiko mengalami trauma. Tujuan: Bagaimana menegakkan diagnosis dan penatalaksanaan pleomorfik adenoma parotis yang melibatkan RPF. Kasus: Seorang pasien perempuan 27 tahun ditegakkan diagnosis pleomorfik adenoma parotis kanan dengan melibatkan RPF. Terdapat pembengkakan pada leher yang bersifat asimtomatis dan gejala pendorongan faring dan laring yang menyebabkan disfonia, disfagia, dan defisit saraf kranial IX,X,XII. Penatalaksanaan: Pasien telah dilakukan operasi parotidektomi pendekatan transervikaltransparotid dengan preservasi arteri karotis eksterna dan saraf fasialis. Kesimpulan: Biopsi Aspirasi Jarum Halus (BAJAH) dan radiologi merupakan pemeriksaan yang penting untuk menegakkan diagnosis. Penatalaksanaan pleomorfik adenoma parotis yang melibatkan RPF adalah bedah ekstirpasi komplit dengan beberapa pendekatan.

Kata kunci: tumor jinak kelenjar liur, pleomorfik adenoma, ruang parafaring
\end{abstract}

\begin{abstract}
Background: Parotid pleomorphic adenoma is the most common benign salivary gland tumor, while giant parotid pleomorphic adenoma involving the parapharyngeal space (PPS) is rare. It was difficult to diagnose because the clinical presentation of this tumor can be subtle. The management must be performed carefully due to anatomy relation to complex vital structure lead to traumatic injury highrisk. Purposes: How to make diagnosis and management parotid pleomorphic adenoma involving PPS. Case: A female 27 years old with diagnosis was giant parotid pleomorphic adenoma involving PPS. There was asymptomatic swelling of the neck and presence of pushing the pharynx and larynx medially causes dysphonia, dysphagia, and IX,X,XII cranial nerves deficit. Management: The patient has been performed parotidectomy with transcervical-transparotid approaches by preservation of the external carotid artery and facial nerve. Conclusion: Fine Needle Aspiration Biopsy (FNAB) and imaging are essential for diagnostic. The management of parotid pleomorphic adenoma involving PPS is surgical complete extirpation with various approaches.
\end{abstract}

Keywords:benign salivary gland tumor, pleomorphic adenoma, parapharyngeal space

Affiliasi penulis : Bagian Telinga Hidung Tenggorok Bedah Kepala \& Leher Fakultas Kedokteran Universitas Andalas/ RSUP. Dr. M. Djamil Padang

Korespondensi : Sukri Rahman, Bagian THT-KL Fakultas Kedokteran Universitas Andalas/ RSUP. Dr. M.Djamil Padang, Email : sukri_rahman@yahoo.com

\section{INTRODUCTION}

Salivary gland tumors represent $3 \%$ of all head and neck neoplasms. About $60 \%$ to $70 \%$ arise in the parotid gland and the great number of this are benign tumors. Approximately $60 \%$ to $80 \%$ of all benign parotid tumor is pleomorphic adenoma. ${ }^{1,2}$ The incidence of parotid pleomorphic adenoma is about 2,4 in 100.000/ year and more common in female than male. ${ }^{1}$ The exact etiology is unknown, however, it has been reported that the incidence increases after exposure to radiation for long time. ${ }^{1,2}$

Histologically, pleomorphic adenoma is an epithelial tumor of complex morphology. There are consist of epithelial and myoepithelial elements being consist of mucoid, myxoid, or chondroid tissue with variety of patterns and located in a mucopolysaccharide stroma.

The parotid glands are located below the external auditory canals and descend anterior to the angle of the mandible between the skin of the cheek and the masseter muscle. Each parotid gland is divided into superficial and deep lobes by facial nerve. The facial nerve consist of five branches; there are the frontal, zygomatic, buccal, mandibular, and cervical branches. Stensen's ducts, which open into the oral cavity adjacent to the maxillary second molars, are the drainage sites for saliva from the parotid glands. ${ }^{3}$

Most of pleomorphic adenoma originate in the superficial lobe, and more rarely these tumor originate in the deep lobe of the parotid gland. Parotid gland tumor can growth medially involving and occupying parapharyngeal space (PPS). Most of parotid tumor involving PPS origin is from the deep lobe. ${ }^{4-7}$ Oliai $B$ cited Farrag $\mathrm{TY}^{4}$ stated that parotid pleomorphic adenoma is the most common of PPS lesions.

The diagnosis of parotid pleomorphic adenoma involving PPS is difficult to establish because of the clinical presentation of this tumor can be subtle. There are many differential diagnosis of them. Fine Needle Aspiration Biopsy (FNAB) and imaging are essential for diagnostic parotid pleomorphic adenoma involving PPS. ${ }^{4-7}$

The complex anatomy relations of tumor location to neurovascular vital structure causes surgical complete extirpation is very limited and must be performed carefully to avoide traumatic injury highrisk. Various surgical approaches have been 
developed to provide effective and safe access to the PPS. ${ }^{5-8}$

\section{CASE REPORT}

A female 27 years old was present to ENTHS outpatient clinic Dr. M. Djamil hospital Padang on November $22^{\text {nd }} 2012$ with chief complaint swelling at the right neck since 3 years before admission. Swelling became bigger slowly by day and without pain. There was hoarseness since a year before admission. There was difficulty in swallowing, no pain in swallowing. There was cough but sometimes, no difficulty in breathing, no difficulty in opening the mouth, and no headache. There was no blocking of the nose, no history of bleeding from the nose, no buzzing of the ears, and no double vision. There was no skewed face, no swelling at the armpit. There was decrease of body weight more than $10 \mathrm{~kg}$ since a year before admission. There was no fever, no palpitation, no history of sweating on palms and soles. There was history of smoking since a year ago, 2-3 cigarettes per day. There was no history of exposure by radiation.

On physical examination general condition in normal limit. Ears and nose was no abnormality detected. On mouth examination was found tongue deviation to the right side, no trismus, and no mass at the soft palate. On throat found pharyngeal arch were asymmetric, uvula pushed to the left side, right tonsil pushed medially - left tonsil T1 not hyperemic, posterior pharyngeal wall was no swelling. On nasoendoscopy was no mass at nasopharyngeal region. On fiber optic telelaryngoscopy was found epiglottic was normal, right arytenoid was pushed medially, right ventricular band and vocal cord was pushed medially and right vocal cord movement was fixated, glottic rim was open, no standing secretion on pyriform sinuses.

On physical examination of right parotid to neck region was found mass with $11 \times 10 \times 6 \mathrm{~cm}$ in size, well defined, not hyperemic, solid, mobile, not tenderness, not fluctuative and no cystic in palpation. There was pulsatile in palpation at anterolateral part of the mass (figure 1). On facial nerve examination there was no facial paresis. On neck region there was no lymph nodes enlargement. On chest examination there was no sign of upper airway obstruction, no rhonchi, and no wheezing. On upper extremities examination there was tremor at right hand and no sweating on palms.

Working diagnosis was suspicious benign right parotid gland tumor with IX,X,XII nerves paresis. Differential diagnosis were benign thyroid tumor, peripher neurogenic tumor, and paraganglioma carotid body. Planned to perform Fine Needle Aspiration Biopsy (FNAB), Computed Tomography (CT scan) of neck region, thyroid function laboratory examination (T3, T4, TSH), thorax x-ray and angiography.

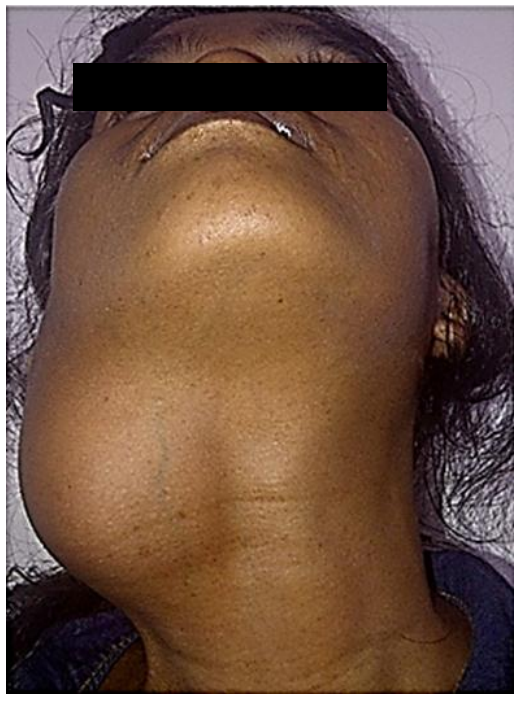

Figure 1. On physical examination of right parotid to neck region was found mass with $11 \times 10 \times 6 \mathrm{~cm}$ in size.

On FNAB histopathology examination was concluded benign tumor that fit the description pleomorphic adenoma. On neck region CT scan was found hipodens mass appearance at right parotid region, pharynx and larynx

was pushed to medial. The mass was occupying right PPS. There was no calcification and no destruction of laryngeal cartilages. The conclusion was extensif right parotid tumor to PPS (figure 2). Laboratory findings of thyroid function were in normal limit. On thorax x-ray was found in normal limit.

The patient was diagnosed with right parotid pleomorphic adenoma involving PPS. Planned to perform parotidectomy, joint operation with plastic reconstruction subdivision to prepare the closure surgical defects (if necessary). The patient was informed consent and prepared blood transfusion.

On laboratory examination was found haemoglobin $13,4 \mathrm{gr} / \mathrm{dl}$, leukocyte $10.700 / \mathrm{mm}^{3}$, thrombocyte $347.000 / \mathrm{mm}^{3}$, haematocryte $38 \%$, PT $10,6 "$ and APTT 38,2".

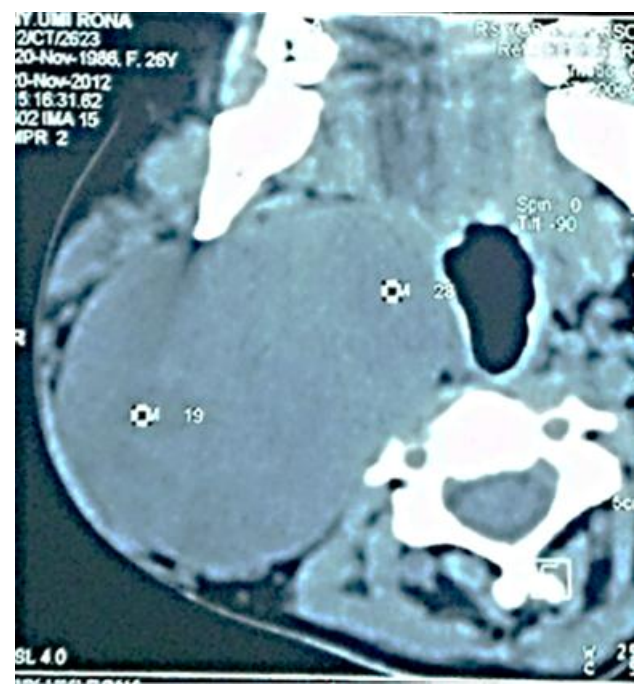




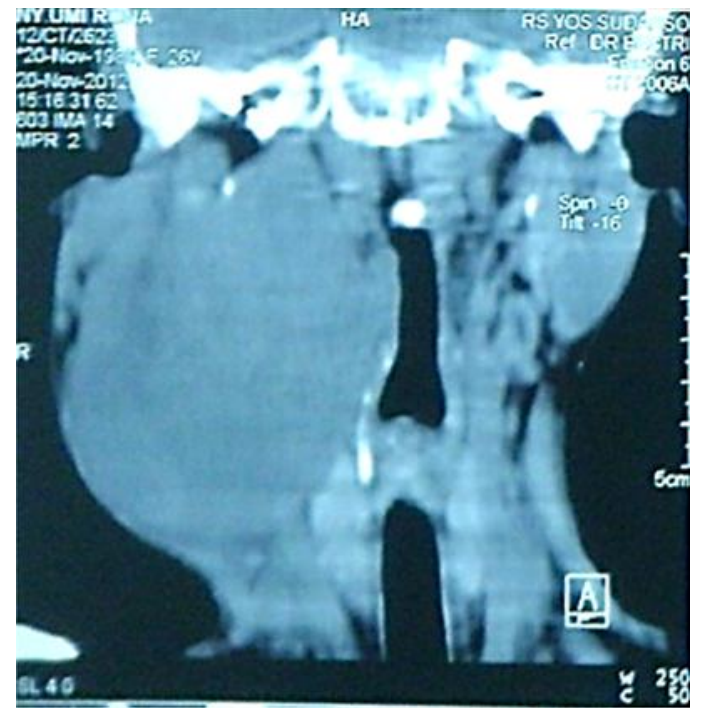

Figure 2. CT Scan axial-coronal of neck region was found extensif right parotid tumor to PPS.

On December, $19^{\text {th }} 2012$, the operation was perfomed. The patient was lying in supine position with the head extended and rotated contralaterally under general anasthaesia. Aseptic and antiseptic procedure, and incision line was marked. Transcervical incision was made approximately at the bottom of right auricule lobule. Skin incision was deeply and separated by sharp dissection, there was found the mass capsulated. Blunt dissection was performed to separate from surrounding structures (posterior belly digastric muscle, superficial lobe parotid gland, and neurovascular vital structures). By retracting mandibular branches divisions of the facial nerve upward, the mass of deep parotid gland was explored using blunt dissection. Incision extended to transparotid, external carotid artery and origin of the posterior facial vein was identified. There was carotid artery pulsation, and preserved. Main trunk of facial nerve was difficult to identified. Stylomandibular ligament, vertebral fascia, pterigomandibular raphe, skull base and hyoid bone was identified and preserved by finger blunt dissection. Carefully, the mass extirpated completely, $9 \times 8 \times 5 \mathrm{~cm}$ in size, solid consistency and multiple lobes. Its cut surface showed white and homogenous (figure 3). Surgical specimen was sent to Pathology Anatomy laboratory. Bleeding was managed. The wound was suture layer by layer. Negatif pressure drain was used. Operation was finished.

Diagnosis after surgery was post medial parotidectomy on indication right parotid pleomorphic adenoma involving PPS. Evaluation after surgery, there were no active bleeding, no facial nerve paresis. On laboratory examination was found haemoglobin $12,3 \mathrm{gr} / \mathrm{dl}$. The patient was given therapy ceftriaxone $2 \times 1 \mathrm{gr} \mathrm{IV}$, tramadol $50 \mathrm{mg}$ drip in $500 \mathrm{ml}$ Ringer Lactat. Suggested soft meal diet.

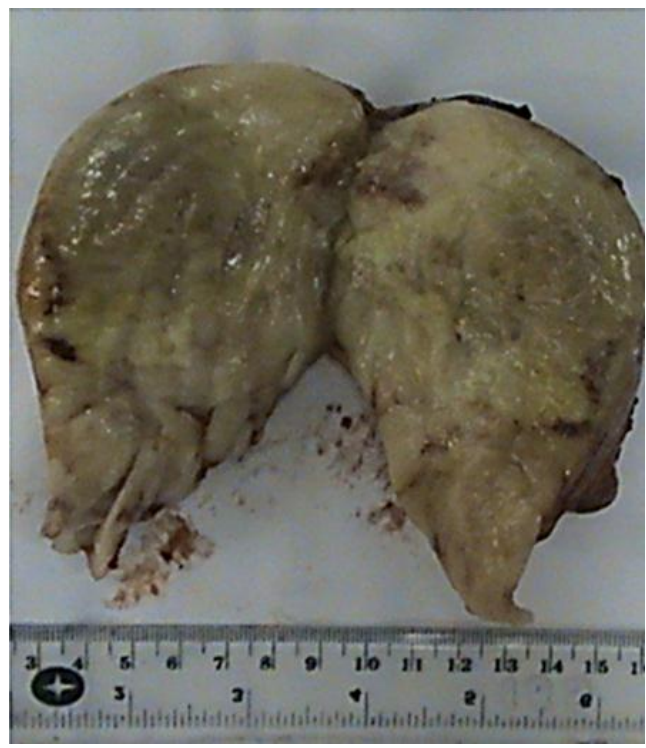

Figure 3. Surgical specimen, the mass was $9 \times 8 \times 5$ $\mathrm{cm}$ in size, solid, multi lobes, cut surface showed white and homogenous.

Follow up on day three, there was no difficulty in swallowing. Hoarseness was decrease. On physical examination at right parotid region were found no sign of infection, no facial nerve paralysis. Negatif pressure drain was found blood $3 \mathrm{cc}$ and drain was removed.

Follow up on day five, the suture was removed alternately (figure 4). On day seven, the suture was removed totally, tongue deviation was decrease than before. On throat examination was found pushing right tonsil to medial minimally. There was no tremor at right hand. The patient was allowed to go home and given therapy were ciprofloxacin $2 \times 500 \mathrm{mg}$ orally, mefenamic acid $3 \times 500 \mathrm{mg}$ orally, B.complex vitamin $2 \times 1$ tablet orally. Suggested control to ENT-HS outpatient clinic next week.

Two weeks after surgery, there was no complaint. On physical examination there was no swelling at the neck, no sweating while chewing. On telelaryngoscopy examination was found larynx pushing to medial minimal

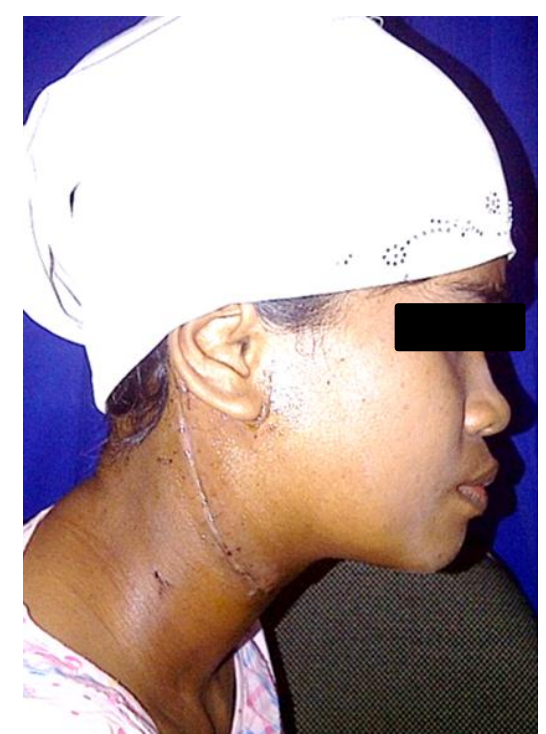

Figure 4. On day seven after surgery. 
On surgical specimen histopathology examination was found the tissue are consist of mesenchim component like fibrotyc tissue, fibrocollagen, neural, and myxoid with hyalinization. The epithelial component are consist of myoepithelial proliferation, with vessel and hystiosit. There are capsul in outer of fibrotyc tissue. The conclusion was pleomorphic adenoma (figure 5).

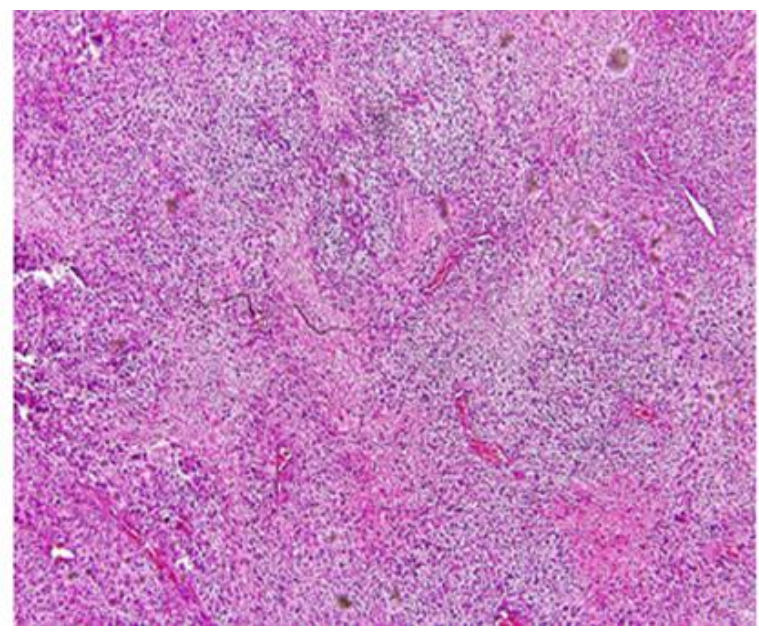

Figure 5. The epithelial component are consist of myxoid, myoepithelial proliferation, with vessel and hystiosit (pleomorphic adenoma).

\section{DISCUSSION}

Parotid pleomorphic adenoma involving to PPS is very rare. PPS lesions account for $0.5 \%$ of all head and neck tumors and the majority are benign $(70-80 \%)$. Salivary gland neoplasms are the most common tumor involving PPS. They arise mainly from the deep lobe of the parotid gland. The most frequent parotid tumors origin is pleomorphic adenoma, followed by warthin tumor. ${ }^{8-10}$ Varghese et all ${ }^{9}$ suggested that occurrence of the pleomorphic adenoma can arise from displaced or aberrant salivary gland tissue within a lymph node in the PPS. Several other large reports found the most common tumor involving PPS is pleomorphic adenoma, followed by neurogenic tumor (schwannoma, paraganglioma and neurofibroma). Other PPS lesions are include thyroid tumor, lymphoma, lipomas, haemangiomas and aneurysm. ${ }^{9-13}$ Tincani et all ${ }^{10}$ found the most common tumor involving PPS are peripheric neurogenic tumor (35\%), pleomorphic adenoma of parotid $(29,4 \%)$, paraganglioma of the carotid body $(29,4 \%)$ and aneurysm of internal carotid artery (5,9\%).

Parotid pleomorphic adenoma involving PPS is difficult to diagnose because of the clinical presentation of this tumor can be subtle. Pleomorphic adenomas frequently present as a painless firm mass and slow growing. As parotid tumors enlarge to PPS, they may grow and compress the IX, X, XI, XII cranial nerves. In some cases, they may be an incidental finding on routine examination. The symptoms are manifested when the tumor becomes larger than 2.5 $3 \mathrm{~cm}$. The symptoms of parotid tumor involving PPS are relate to the prestyloid- poststyloid localization, they include are foreign body sensation (a palpable oral mass), difficult deglutition (dysphagia), otological symptoms (symptoms related to the eustachian tube), hoarseness (dysphonia) and Horner's syndrome. Few reports describe obstructive sleep apnoe symptoms of secondary tumor involving PPS. Clinical symptoms and signs may depend on the direction of extension of the mass. The most frequently noted as a growth pushing the lateral wall of the oropharynx medially or a growth on the neck under the edge of the mandible angle. Generally, they are mobile. ${ }^{8-14,17,18}$

Dimitrijevic ${ }^{14}$ stated that the most common symptoms of parotid tumor involving PPS is presence of growth on the neck (46\%), pain (20\%), dysphagia (13\%), and pharyngeal growth $(9 \%)$. In this case was found the symptoms were dysphagia, dysphonia, IX,X,XII cranial nerves deficit due to pushing the lateral wall of the oropharynx and larynx medially.

Imaging is crucial tools for assessment of parotid tumor involving PPS. Computed tomography (CT) with contrast medium, magnetic resonance imaging (MRI) and contrast angiography, in selected cases, are essential for diagnosis PPS lesions. CT scan was used in defining diagnosis and for planing surgical therapy in the most cases. Contrast CT is an effective imaging examination, thus allowing better definition of normal anatomic structures and delineation of tumor margins. Parotid tumor involving PPS on CT scan show the constrictions of stylomandibular tunnel on tumor growth gives a characteristic "dumbbell" shape. While, MRI is preferred, because of better definition of soft tissue. MRI is better than CT because it provides useful information on tumor localization, extention, and distinguishes tumors of the deep lobe, neurogenic lesions, paraganglioma or carotid body tumors and their relations with the internal carotid artery and adjacent vital structures. Angiography is recommended if paragangliomas or tumor involving the carotid artery is suspected. Angiography should be performed to show the relation of the tumor to the neck great vessel and its blood suply. ${ }^{13-18}$ In this case had performed CT scan only because of lack on facility. On neck region $\mathrm{CT}$ scan examination was found extensif right deep lobe parotid tumor.

FNAB is the modality of choice for obtaining biopsy sample for pleomorphic adenoma. Bozza et all $^{15}$ stated that FNAB is accurate in $90-95 \%$ of PPS lesions cases. Khafif $A$ et all ${ }^{16}$ reported 63 PPS lesions, the overall accuracy of FNAB exceeded $88 \%$. FNAB guided by imaging is recomended for diagnostic of vascular tumor involving PPS. The incision biopsy could have been avoided. However, it is to be emphasized that the incision biopsy is no more advocated for salivary gland tumors due to the risk of tumor seeding and subsequent multinodular recurrence. Incision biopsy is suggested in suspicious of malignant tumors. ${ }^{14-18}$

The treatment of parotid pleomorphic adenoma involving PPS is essentially surgical complete extirpation by parotidectomy and considered to be the gold standard. Parotidectomy are divided based on location of the tumor, are include lateral (superficial) parotidectomy. medial (profunda) parotidectomy, and total parotidectomy. However, the management tumor involving PPS needs to confirm careful preoperative diagnostic procedure to plan surgical treatment with safe approach and reduces complications, aesthetic functional damage and risk recurrence. ${ }^{15,19,20}$

PPS is however, a complex anatomic region located, forming an inverted pyramid from the skull base superiorly to the hyoid bone inferiorly. Laterally to the fascia on the medial aspect of the masticator 
space and the fascia over the deep surface of the parotid gland. Medially to the buccopharyngeal fascia that covers the outer aspect of the pharyngeal constrictor muscles. Anteriorly to the pterigomandibular raphe. PPS is typically comprised by the tensor veli palatine muscle fascia into two subdivision which is poststyloid and prestyloid. Poststyloid PPS contains of the carotid artery, internal jugular vein, IX, X, XI, and XII cranial nerves and sympathetic chain. Access is restricted by the vertical ramus of the mandible, the parotid gland, the facial nerve and the styloid process with its muscular and ligamentous attachments. Poststyloid tumors are usually benign. The prestyloid PPS is bordered anterolaterally by the medial pterygoid muscle, and posterolaterally by the deep lobe of the parotid gland extends from the hyoid bone inferiorly, to the skull base superiorly and contains mainly parapharyngeal fat. $^{15,18,21}$ In this case the tumor was present on prestyloid and poststyloid PPS.

Due to the PPS's anatomic complexity, location and surrounding vital structures, causes extirpation of tumors from this space can prove challenging to the head and neck surgeon. The great anatomic distortion of the zone made it difficult to identify the trunk of the facial nerve. ${ }^{11,18,21}$

Parotidectomy with facial nerve preservation is the method of choice in treatment benign tumors of the parotid gland. It is generally accepted that the standard treatment of parotid pleomorphic adenoma involving PPS is complete removal of the tumor, with two criteria are include wide intra-operative visibility for safe operation and minimal functional or cosmetic effects. ${ }^{12,16,22}$

There are several surgical approaches according to Dimitrijiveric ${ }^{14}$ that described are include transcervical, transcervical transparotid, transcervical transmandibular and transoral approaches. Mandibulotomy approach can be performed if necessary to improve exposure visibility. The selection of which approach depends on location, size and extention of the tumor. The transcervical transparotid approach provides to large size of the tumor as excellent access to the PPS and allowing dissection of the adequate neurovascular control. Surgery of tumor involving PPS had been performed in most patients via the transcervical or transcervical transparotid approach with no need any major reconstructive procedures. $12,16,22 \mathrm{In}$ this case used transcervical transparotid approach.

A primary closure of surgical defect tumor involving PPS was used when possible. In selected case rotational flap (cervicofacial flap) were required. Large defect was used regional flap (pectoralis major myocutaneus flap, temporalis muscle flap) or free flaps (radial forearms fasciocutaneus flap or scapular flap). Large mucosal oropharyngeal defects were required with radial forearms fasciocutaneus flap. ${ }^{16,22}$ In this case didn't need reconstructive procedure.

There are several complications of the parotid tumor involving PPS surgical extirpation. The early complications are include, bleeding, facial nerve dysfunctions, infection, trismus and seroma. Late complications are include Freys syndrome, recurrent tumor, poor cosmetic, soft tissue deficit, hypertrophic and scar. ${ }^{20,24}$ In this case, there was no early and late complications.

The characteristics of pleomorphic adenoma are high recurrence rate and infrequent malignant conversion. Histologically, pleomorphic adenoma show incomplete encapsulation with pseudopodes extensions or are left in the gland giving rise to multiple noduler recurrences or risk of malignant change. According to Melkundi ${ }^{1}$ there was up to $43 \%$ of recurrence after surgical extirpation as pleomorphic adenoma don't have true capsule. Some authors observed that almost all recurrences were multicentric with incomplete excision. Primary multicentricity might influence recurrence rate, so treatment radical excision or total parotidectomy often becomes challenging, probably not only for intrasurgical ruptures or the presence of tumor pseudopodia penetrating throughout adjacent normal glandular. ${ }^{20-23,25,26}$

Treatment of patients with recurrent pleomorphic adenoma is difficult. Indeed, in most cases, it would be more accurate to speak of residual disease to the patient before operation. Revision surgery in the parotid area has a higher morbidity. It is logical to infer that the recurrence rate would be higher after surgery for parapharyngeal tumor of similar histology, as a wide extirpation may not be possible at the site due to proximity of vital structures. $23,25,27$

In conclusion, knowledge of the differential diagnosis parotid tumor involving PPS and through working diagnosis by performed imaging and FNAB should allow for an acurate diagnosis and safe surgical extirpation.

\section{REFERENCES}

1. Melkundi $M$, Babaji $P$, Saikhedkar $R$, Chaluvaiah MB. Pleomorphic Adenoma of Parotid Gland: A Case Report. Oral \& Maxillofacial Pathology Journal. 2012;3:228 31.

2. Ladeinde AL, Adeyemo WL, Bamgbose BO, Ogunlewe MO, Ajayi FO. Concurrent pleomorphic adenoma in parapharyngeal space and submandibular gland. World Journal of Surgical Oncology 2004;2:1-5.

3. Holsinger FC, Bui DT. Anatomy, Function, and Evaluation of Salivary Glands. In: Myers EN, Ferris RL editors. Salivary Gland Disorders. Springer: Berlin; 2007. p. 1-14.

4. Farrag TY, Lin FR, Koch WM, Califnao JA, Cummings CW, Farinola MA, et all. The role of pre-operative CT-guided FNAB for parapharyngeal space tumors. Otorhinolaryngology Head and Neck Surgery 2007;126:411-14.

5. Giddings CEB, Bray D, Rimmer J, Williamson P. Pleomorphic adenoma and severe obstructive sleep apnoea. The journal of Laryngology and Otology 2005; 119: 226-9.

6. Sergi B, Limongelli A, Scarano E, Fetoni AR, Paludetti G. Giant deep lobe parotid gland pleomorphic adenoma involving the parapharyngeal space. Report of three cases and review of the diagnostic and therapeutic approaches. Acta Otorhinolaryngologica 2008;28: 261-5.

7. Ungari C, Paparo F, Colangeu W, lannetti G. Parotid glands tumours: overview of a 10years experince with 282 patients, focussing on 231 benign epithelial neoplasms. European review for medical and pharmacological sciences 2008; 12:321-5. 
8. Breeze J, Ramesar K, Williams, Howlett. Pleomorphic adenoma arising from accessory parotid tissue presenting as dysphonia. Journal Army Med Corps 2008; 154(1): 57-9.

9. Varghese BT, Sebastian P, Abraham EK, Mathews A. Pleomorphic adenoma of minor salivary gland in the parapharyngeal space. World journal of surgical oncology 2003; $1: 2$.

10. Tincani AJ, Martins AS, Altemani A, Scanavini RC, Barreto G, Valerio JB, et all. Parapharyngeal space tumors: considerations in 26 cases. Sao Paulo Med J/Rev Paul Med 1999; 117(1):34-7.

11. Papadogeorgakis N, Petsinis V, Kostakis G, Alexandridis C. Parapharyngeal space tumors: surgical approaches in a series of 13 cases. Journal Oral Maxillofacial Surgery 2012;39:2443-50.

12. Zhi K, Ren W, Zhou H, Wen $Y$, Zhang $Y$. Management of parapharyngeal spacetumors. Journal Oral Maxillofacial Surgery 2009;67:1239-44.

13. Cetik F, Yaziji D, Ugus A. A thyroid tumor extending to parapharyngeal space. BMC Ear Nose and Throat Disorders 2006;6(3): 1-7.

14. Dimitrijiveric MV, Jesic SD, Arsovic NA, Tomanovic NR. Parapharyngeal space tumors: 61 case reviews. Journal Oral Maxillofacial Surgery 2012; 39:983-9.

15. Bozza F, Vigili MG, Ruscito P, Marzetti F. Surgical management of parapharyngeal space tumors: result of 10-year follow up. Acra otorhinolaryngology 2009;29:10-15.

16. Khafif A, Segev Y, Kaplan DM, Gil Z, Fliss DM. Surgical Management of parapharyngeal space tumors: a 10-year review. Ootorhinolaryngology Head and Neck Surgegry 2005;132: 401-6.

17. Pistorio V, Teggi R, Bussi M. Simultaneous pleomorphic adenoma of the parapharyngeal space and contralateral submandibular gland: Case report. Acta Otorhinolaryngologica Italica 2008;28:257-60.

18. Biswas S, Saha S, Sadhu A. Pictorial essayParapharyngeal space lesion. Ind J Radiol Imag 2005;15:41-6.
19. Laza LR, Cossio OI, Perla AG, Gutsado JH, Perez LG. Giant pleomorphic adenoma in the parapharyngeal space: Report of 2 cases. Journal Oral Maxillofacial Surgery 2006; 51924.

20. Oh YS, Eisele DW. Salivary Glands Neoplasma. In: Bailey BL, Johnson JT, Shawn N. Editors. Head and Neck SurgeryOtolaryngology, $4^{\text {th }}$ Ed. Philadelphia: Lippicott Williams \& Wilkins; 2006. p. 1513-33.

21. Vaidhyanath $R$, Harieswar S, Kendall C, Conboy P. Pleomorphic adenoma arising from the tail of the parotid gland-value of preoperative multi planar imaging: a case report. Cases Journal 2008;1-3.

22. Cossio PI, Cardero EG, Perez LMG, Rodado ML, Perla AG, Esteban F. Management of parapharyngeal giant pleomorphic adenoma. Journal Oral Maxillofacial Surgery 2011;15:211-6.

23. Wittekindt C, Streubel K, Arnold G, Stennert E, Guntinas-Linchius O. Recurrent pleomorphic adenoma of the parotid gland: analysis of 108 consecutive patients. Available from: www.interscience.wiley.com. 2007.

24. Amin A, Mostafa A, Rifaat M, Nabawi A, Shallan M, Rabie A, et all. Parotidectomy for benign parotid tumors: An aesthetic approach. Journal of Egyptian national cancer institute 2011;23:67-72.

25. De Zinis LOR, Piccioni M, Antonelli AR, Nicolai P. Management and Prognostic Factors of Recurrent Pleomorphic Adenoma of Parotid Gland: Personal Experience and Review of the Literature. Eur Arch Otorhinolaryngology 2008;265: 447-452.

26. Hakeem AH, Hazarika B, Pradhan SA, Kannan R. Primary pleomorphic adenoma of minor salivary gland in the parapharyngeal space. World journal of surgical oncology 2009;7: 85.

27. Takahama A, Elias D,Perez C, Magrin J, Almelda OP, Kowaiski LP. Giant pleomorphic adenoma of parotid gland. Med Oral Pathol Oral Cil Buccal 2008;1:58-60. 